\title{
EREG Gene
}

National Cancer Institute

\section{Source}

National Cancer Institute. EREG Gene. NCI Thesaurus. Code C24375.

This gene plays a role in cellular biogenesis, organization and proliferation. 